Volume and Issues Obtainable at Center for Sustainability Research and Consultancy

Journal of Accounting and Finance in Emerging Economies

ISSN: 2519-0318 ISSN (E) 2518-8488

Volume 3: Issue 1 June 2017

Journal homepage: www.publishing.globalcsrc.org/jafee

\title{
Determinants of Quality Accounting Information Disclosure
}

\author{
${ }^{1}$ SaginOghenekowhodo Super, ${ }^{2}$ Nikhil Chandra Shil
}

${ }^{1}$ Finance and Admin Officer, PAN/NISONM, Maternal and Child Survival Program (MCSP), Abuja, Nigeria

${ }^{2}$ Associate Professor, Department of Business Administration, East West University, Dhaka, Bangladesh

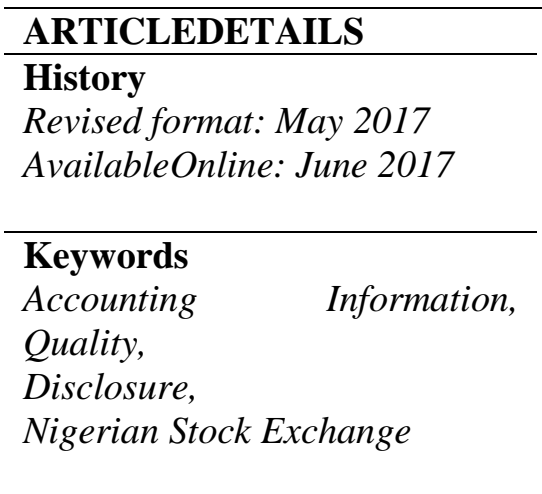

JEL Classification:

Q56

\begin{abstract}
Purpose: This study aims at examining the factors determining the quality of accounting information disclosure in Nigerian firms. The study made use of secondary data obtained from the Nigerian stock exchange. Ordinary least square regression technique was used to test the hypothesis for this study. The study found a positive relationship between firm size and disclosure quality. Institutional ownership, firm performance and earnings per share also had a positive relationship with disclosure quality. Firm leverage was found to have a negative relationship with disclosure quality. This study recommends that firms should introduce the idea of institutional ownership and also leverage usage should be minimized.
\end{abstract}

(C) 2017 The authors, under a Creative Commons AttributionNonCommercial 4.0

Corresponding author's email address: nikhilacc@yahoo.com

Recommended citation:Super,S.O. \&Shil,N.C (2017). Determinants of Quality Accounting Information Disclosure.Journal of Accounting and Finance in Emerging Economies, 3(1) 79-86.

DOI:https://doi.org/10.26710/jafee.v3i1.94

\section{Introduction}

The study attempts to explore the factors that explain the quality of disclosed accounting information by firms listed in Nigerian Stock Exchange. The importance to advance our understanding of disclosure practices by companies is pointed by the institutional part that plays the information disclosed by a company. Accounting information is used to construct an interface between the organization and its environment who seek to pursue an interest in it (Crozier \& Friedberg, 1977 as cited in Michailesco, 1999). Visibility of the organization towards the world outside depends on the quality of accounting information. But the visibility also depends on the company's negotiation margins and its economic and social objectives. Thus, disclosure quality is determined by an internal expert judgment (Choi \& Mueller, 1992 as cited in Michailesco, 1999). The role of accounting information is very important in managing an organization and implementing an internal control system. It is urgent to know whether accounting information fits with organizational requirement for information communication and control to supplement managerial decision making needs (Nicolaou, 2000). Although the information generated from an accounting system can be effective in decision making process; the purchase, installation and usage of such a system is desirable when the benefits exceed the cost. Benefit of accounting information system can be evaluated by its impact on improvement of decision-making process, enhancement of quality of disclosed accounting information, performance evaluation, internal controls and facilitating company's transaction. 
Akintoye (2008) opined that accounting information is the most basic input into any informed economic decision making. Yet we are not aware of any structural research into whether this primary input possess the attributes required to enable it play creditably its information assigned or presumed role in such decision tasks. The amount of information disclosed by organizations in corporate reports has considerably expanded in recent times. Although reliability on some has proven little to be desired with the recent increase in collapse of world class financial institutions among others which necessitated the increased pressure for optional disclosure in corporate reports. The major source pressure for disclosure has been the financial and investment community. The research intends to investigate the determinants of quality of disclosed accounting information.

\subsection{Statement of the Research Problem}

Numerous studies have been carried out on the quality of disclosed accounting information. Quality as we know is one of the key characteristics of information. A wide range of users seriously rely on accounting information to take various decisions of their interests. It is very important to ensure that the decisions that the users take are backed by quality information which strengthen the public confidence on accounting systems. Quality of disclosed accounting information affects investors' decisions, management's decision as well as the future performance of the firm. Also recent happenings in the corporate world especially in the banking sector have reawakened the need to focus and carryout findings on the quality of disclosed accounting information. In the light of these, the current research seeks the answer to the following questions:

a) Does the quality of disclosed accounting formation relate to the firm's size?

b) Does the quality of disclosed accounting formation relate to the firm's leverage?

c) Does the quality of disclosed accounting formation relate to the firm's performance?

\subsection{Objectives of the Study}

The main objective of the study is to examine the determinants of quality of disclosed accounting information. The specific objectives are:

a) To ascertain if the quality of disclosed accounting information is related to the firm's size.

b) To verify if the quality of disclosed accounting information is related to the firm's leverage.

c) To examine if the quality of disclosed accounting information is related to the firm's performance.

\subsection{Scope of the Study}

The study focuses on the determinants of quality of disclosed accounting information. The population of the study consists of all the quoted companies in the Nigerian Stock Exchange, while the sample size is five (5) quoted companies operating in Nigeria. The time frame of the study is five (5) years i.e. from 2010 to 2015. Geographically, the study includes Benin City, Edo State.

\section{Literature Review}

Traditionally, the quality of accounting information disclosed by firms is measured by estimating value relevance of accounting numbers of stock market (Ball and Brown, 1968). Quality accounting information is incorporated into investors' valuation models and aids in decision making. Another approach to measure quality of disclosed accounting information is to study conservatism in accounting (Garcia Lara and Mora, 2004). Based on JFRS principles, in order to provide high quality accounting information, firms should prepare financial statements disclosing reliable and relevant information. Quality of accounting information can also be measured by degree of earnings management. Managed earnings are deemed to distort the quality of accounting information and give misleading signals to investors (Dechow, 1996).

The purpose of disclosed quality accounting information is to provide imperative success to the systems. International investors can be viewed as accounting information with the highest quality as firms are more likely to employ sophisticated timely accounting in order to provide financial reports targeted for 
international investor's needs. Decision making as a purpose of quality secondary information disclosed which is natural incentives behind preparation of accounting information by a company which may be reviewed as an indirect measure of quality accounting information disclosed, choice, being a natural purpose of accounting in general which correspond to decision usefulness principle of accounting information.

If company considers that the main purpose for preparing accounting information is tax authorities, we may question the quality of financial statements, where not the investors' but tax authorities need to shape accounting numbers. It is characteristic for transitional economics that accounting data for the financial statement is prevailed by tax considerations.

Principal-agent theory asserts that the principal should monitor the agent in order to prevent a potential risk of expropriation. Institutional investors are the major suppliers of funds to financial markets. They often hold a large proportion of listed firm's capital which allows them to have a strong position. This strong position added to their long term experience in finance helps them in monitoring managers. Corporate disclosure is a low-cost mechanism for monitoring managers' performance; therefore institutional investors have incentives to constrain managers to disclose relevant information. Institution with a large number of portfolio stocks prefer higher quality disclosure as a way to offset monitoring costs.

\subsection{Empirical Review}

Alexander (2006) conducted a research on the effect of ownership structure on accounting information and concluded that the kind of ownership present in a firm go a long way in determining the quality of accounting information disclosure. Chiraz et al. (2007) studied disclosure quality of accounting information using the theoretical framework of agency theory and found that public ownership increases agency costs and therefore should increase shareholder's information need and enhance disclosure. Ismail and King (2007) studied factors influencing alignment of accounting information using 214 firms and suggested that accounting information system is related to firm's accounting disclosure quality.

Noraya and Siti (2007) conducted a research on significance of accounting information in explaining market and book values and found out that the market and book values of firms have a relationship with accounting information disclosure quality. Protcea (2008) conducted research on optimizing Investment Decision through Informative Accounting reporting and recommends a strict compliance with prescribed accounting information disclosure requirement, and also advocated transparency in accounting related forecast. Fanklin et al. (2008) conducted a study on disclosure quality and market liquidity. They found out that firms with higher quality disclosure have lower effective bid-ask spread and lower adverse selection spread components, they also found that firms with higher quality disclosure have lower quoted depths.

\subsection{General Discussion}

Quality accounting disclosures are one means to reduce information asymmetries across traders and increase the ability of equity traders to effectively execute stock trades when desired and at reasonable costs. In this way, high quality disclosure can enhance market liquidity. Quality accounting also affect the ability of the firm to attract investors to itself. From our review, it was shown that quality of accounting information disclosure is dependent on some factors like liquidity, purpose of accounting information, incentive behind preparation of accounting information, seize, return, correlation, analyst and ownership. From all these one thing is clear. For any organization to attract investors, improve its value of equity and enhance firm performance, it must take due care in preparing and disclosing its accounting information so as to reflect the quality of accounting information disclosed.

\section{Research Design}


Research design addresses the planning of scientific enquiry, designing a strategy for finding out something. It is the program that guides the investigator in the process of collecting, analyzing and interpreting observation. Research design could be said to be the specification of acquired information needed for the research and will be also considered with the measuring instrument.

\subsection{The Population}

According to Ehieduru (1990:52), population is the totality summation or aggregate of all cases which poses a set of well-known characteristics or which conform to some designated set of specification. It is the totality of the objective being studied from which may select a sample. Therefore, the population of this study comprises of all manufacturing firms quoted on the floor of the Nigeria stock exchange market.

\subsection{The Sample and Sampling Technique}

Coping with the population of the study the exhaustive, consequently resources are made to sample drawn from the population. Also, statistical laws reveal that the statistics computed from sample data are usually accurate. The sample of this study is drawn from companies listed under the Nigerian stock exchange. Purposive sampling method, which is the process of selecting a sample to suit our purpose in order to minimize obvious constraints, was adopted in selecting companies from the sample size available.

\subsection{Regression Analysis}

Regression analysis determines the specific function relating the dependent variable to the independent variable. It attempts to establish the relationship between variables that is to study the functioning relationship between them and there by provide the mechanism of prediction or forecasting. There are several types of regression analysis; the type chosen depends on the nature and complexity of the relationship being studied. For the purpose of this study, the multiple regression technique would be employed.

\subsection{Model Specification}

$\mathrm{DQ}=\mathrm{F}($ Size, Insown, Flev, Perf, Return)

DQ $=\beta_{0}+\beta_{1}$ SIZE $+\beta_{2}$ INSOWN $+\beta_{3}$ FLEV $+\beta_{4}$ PERF $+\beta_{5}$ RETURN $+\varepsilon$

$\mathrm{DQ}=$ Quality of accounting information disclosure is measured by degree of earnings management, thus, managed earnings are deemed to distort the quality of accounting information and give misleading signals to investors (Dechow, 1994).

SIZE $\quad=$ Firm Size Measured using natural log of equity

INSOWN $\quad=$ Measured by percentage of shares owned by institutional shareholders

FLEV = Measured using long term debt/total

Perf $\quad=$ Performance Measured Using $\mathrm{ROA}=\mathrm{PAY} \div \mathrm{TA}$

ROA $=$ Return on Assets

PAY $=$ Profit After Tax

$\mathrm{TA}=$ Total Asset

Return $\quad=$ Measured using earning per share

$\varepsilon \quad=$ Error term

\subsection{Descriptive Statistics}

The descriptive statistics of the variables used in the analysis are presented in Table 1 below. Disclosure quality is the dependent variable and constitutes the main variable of interest; disclosure quality has a mean value of -262.037 and a median value of -0.00012. It had a maximum value of 13.31932 and a minimum value of value of -5.50549. Disclosure quality was negatively skewed with value of -13.7842 . The standard deviation of disclosure quality is 3638.591 which are far from the mean value of -262.037. This suggests a high degree of variability of the data between time series. Earnings per share had the highest mean of 101.0683, and also median value of 55. Every other data was positively skewed except for disclosure quality and firm size. 
Table 1: Descriptive Statistics

\begin{tabular}{|l|r|r|r|r|r|r|}
\hline & \multicolumn{1}{|c|}{ DQ } & \multicolumn{1}{c|}{ SIZE } & \multicolumn{1}{c|}{ INSOWN } & \multicolumn{1}{c|}{ FLEV } & \multicolumn{1}{c|}{ PERE } & \multicolumn{1}{c|}{ EPS } \\
\hline Mean & -262.037 & 6.310613 & 34.4629 & 1.34049 & 0.4595 & 101.0683 \\
\hline Median & -0.00012 & 6.36040 & 37.89 & 0.09193 & 0.070203 & 55 \\
\hline Maximum & 13.31932 & 7.930666 & 88.74 & 192.1373 & 60.21616 & 967 \\
\hline Minimum & -5.50549 & 4.254089 & 0 & 0.00082 & -0.08396 & -183 \\
\hline Std. Dev & 3638.591 & 0.774303 & 30.44485 & 13.87388 & 4.343056 & 133.4647 \\
\hline Skewness & -13.7842 & -0.07793 & 0.075444 & 13.58826 & 13.60786 & 2.227269 \\
\hline Kurtosis & 191.0046 & 2.577119 & 1.449409 & 187.2689 & 187.6441 & 11.90058 \\
\hline Probability & 0 & 0.44188 & 0.000058 & 0 & 0 & 0 \\
\hline Jarque-Bera & 290350.2 & 1.633432 & 19.51794 & 278994.1 & 280124.5 & 796.633 \\
\hline Sum & 050573.1 & 1217.948 & 6651.34 & 258.7145 & 88.68359 & 19506.18 \\
\hline Sum sq. Dev. & $2.54 \mathrm{E}+09$ & 115.1127 & 177962.7 & 36957.06 & 3621.529 & 3420060 \\
\hline Observation & 193 & 193 & 193 & 193 & & \\
\hline
\end{tabular}

\subsection{Empirical Relationships between Quality and Accounting Information}

In an attempt to explore the relationship amongst variables used in this study, correlation analysis was carried out. Table 2 shows the relationship amongst variables. The table shows that the co-efficient of correlation of a variable within respect to itself is 1.00 . The analysis showed a positive relationship between disclosure quality and firm size. Also a positive relationship was noticed amongst disclosure quality, institutional ownership was noticed amongst disclosure quality, institutional ownership and firm leverage. Performance and earnings per share also exhibited a positive relationship with disclosure quality. In terms of coefficient, the highest coefficient was between disclosure quality and size.

Table 2: Correlation Analysis: Determinants of Quality of Accounting Information

\begin{tabular}{|c|c|c|c|c|c|c|}
\hline \multicolumn{7}{|c|}{$\begin{array}{l}\text { Covariance Analysis: Ordinary } \\
\text { Date: 02/15/16 Time 21:26 } \\
\text { Sample: } 1200\end{array}$} \\
\hline \multicolumn{7}{|c|}{ Balance sample (List-wise missing value deletion) } \\
\hline & DQ & SIZE & INSOWN & FLEV & PERE & EPS \\
\hline \multirow[t]{2}{*}{ DQ } & 1 & & & & & \\
\hline & ---- & & & & & \\
\hline \multirow[t]{2}{*}{ SIZE } & 0.192289 & 1 & & & & \\
\hline & 0.00074 & ---- & & & & \\
\hline \multirow[t]{2}{*}{ INSOWN } & 0.55427 & 0.210336 & 1 & & & \\
\hline & 0.4439 & 0.00033 & ---- & & & \\
\hline \multirow[t]{2}{*}{ FLEV } & 0.0003239 & -0.08384 & -0.07677 & 1 & & \\
\hline & 0.9643 & 0.2463 & 0.2886 & & & \\
\hline \multirow[t]{2}{*}{ PERF } & 0.005873 & -0.07736 & -0.0699 & 0.993232 & 1 & \\
\hline & 0.9354 & 0.2849 & 0.334 & 0 & --- & \\
\hline \multirow[t]{2}{*}{ EPS } & 0.029418 & 0.48493 & 0.103842 & -0.02904 & -0.3338 & 1 \\
\hline & 0.6847 & 0 & 0.1507 & 0.6885 & 0.6449 & -- \\
\hline
\end{tabular}

\subsection{Regression Analysis}

The results of the initial analysis are presented in Table 3, while the final result is reported in Table 4. From the initial output, it can be seen that firm leverage and earnings per share had a negative relationship with disclosure quality, while size, institutional ownership and performance all had a positive relationship with disclosure quality. This means that size, institutional ownership and performance are strong determinants of quality of accounting information disclosure. The R-squared value of 0.04 is very low and indicates that only 0.04 percent of the systematic variation in disclosure quality is explained by the model. This indicates that the estimated model do not have a good predictive power since about 99.96 percent of the variations in the dependent variable was left unaccounted for. Hence use can argue that a significant relationship does not exist between disclosure quality and all the independent variables combined. The Durbin-Watson statistic of 1.04 indicates the presence of autocorrelation in the model. 
Table 3: Result of Regression Analysis

\begin{tabular}{|l|c|c|c|}
\hline Variables & Coefficient & T ratio & Prob. \\
\hline C & -6948.55 & -2.946606 & 0.0036 \\
\hline SIZE & 10833.377 & 2.757232 & 0.0064 \\
\hline INSOWN & 2.013114 & 0.229531 & 0.9512 \\
\hline FLEV & -9.96246 & -0.061309 & 0.9512 \\
\hline PERF & 50.13056 & 0.096664 & 0.9231 \\
\hline EPS & -2.26897 & -1.014669 & 0.3116 \\
\hline R-square $=0.04$ & D.W. 1.04 & \\
\hline
\end{tabular}

A first auto-regression technique was used to correct the autocorrelation problem in the initial output. From the final output, disclosure quality had a positive relationship with size, institutional ownership, performance and earnings per share while firm leverage had a negative relationship with disclosure quality. This means that size, institutional ownership, performance and earning per share are important determinants of quality of accounting information disclosure. The R-squared value is now 0.03 which means that only 0.03 percent of the systematic variations in disclosure quality is explained by the independent variables. This indicates that the estimated model do not have a good predictive power since about 99.97 percent of the variable is left unaccounted for. Hence, we can argue that a significant relationship does not exist between disclosure quality and all the independent variables combined. The Durbin-Waston statistics is now 2.18 indicating the absence of auto correlation.

Table 4: Result of Revised Regression Analysis

\begin{tabular}{|l|c|c|c|}
\hline Variables & Coefficient & T ratio & Prob \\
\hline C & -2.797894 & -0.856108 & 0.3931 \\
\hline SIZE & 0.279487 & 0.513974 & 0.6079 \\
\hline INSOWN & 0.020543 & 1.721383 & 0.0869 \\
\hline FLEV & -0.043589 & -0.19974 & 0.8419 \\
\hline PERF & 0.168753 & 0.242297 & 0.8088 \\
\hline EPS & 0.001463 & 0.483808 & 0.6291 \\
\hline R-square $=0.03$ & D.W. 2.18 & \\
\hline
\end{tabular}

\subsection{Test of Hypothesis}

H1: Quality of accounting information disclosure is positively related to the firm size.

From the result of the analysis, firm size has a positive relationship with disclosure quality. We therefore accept the null hypothesis and reject the alternative hypothesis.

H2: Quality of accounting information disclosure is positively related to firm leverage.

From the result of the analysis, firm leverage had a negative relationship with disclosure quality. We therefore accept the alternative hypothesis and reject the null hypothesis.

H3: Quality of accounting information disclosure is positively related to firm performance.

From the result of the analysis, firm performance had a positive relationship with disclosure quality. We therefore accept the null hypothesis and reject the alternative hypothesis.

\subsection{Summary of Findings}

This study was carried out to examine the determents of quality of accounting information disclosure. The result of the empirical analysis showed that:

1. Firm size had a positive relationship with disclosure quality.

2. Institutional ownership had a positive relationship with disclosure quality. 
3. Firm leverage had a negative relationship with disclosure quality.

4. Firm performance had a positive relationship with disclosure quality.

5. Earnings per share had a positive relationship with disclosure quality.

\section{Conclusion}

The aim of this study was to empirically examine the determinants of quality of accounting information disclosed over the years which have been subject to a lot of criticism following the recent scandals across the world. Proper information has to be disclosed due to the fact that a lot of persons need the information for different reasons. Thus the information reported has to be qualitative. This study made use of five variables with disclosure quality as dependent variable. We found size, institutional ownership, performance and earning as strong determinants of disclosure quality. Firm leverage was found to be a weak determinant of disclosure quality. This study recommends that firms should embrace the issue of institutional ownership and also minimize leverage employed by a firm.

\section{Recommendations}

Few recommendations of this research are given below:

1. Institutional ownership should be encouraged and right atmosphere should be ensured for them to invest in firms. Good disclosure quality attracts potential for profitable opportunities which increase the interest of institutional investors. Institutional investors hold large proportions of capital and have strong professional experience which they use to monitor managers' performance and have incentives to constraint management to disclose relevant information thereby increasing disclosure quality.

2. Investments that would lead to increase in firm size should be encouraged as size was a determinant of disclosure and provided a better disclosure quality.

3. The use of leverage on disclosure quality: debt may be used to align managers and shareholders interest. High leverage increase pressure on managers and limits their actions thereby reducing disclosure quality.

4. Highly profitable projects should be undertaken by firms. Profitability contributes greatly to disclosure quality. Firms who do well or make profit are quick to disclosure correct information as it enhances their corporate value.

\section{References}

Akintoye, I. R. (2008).Budget and Budgetary Control for Improved Performance.European Journals of Economics, Finance and Administrative Science, issue 12, 9-11. Retrieved from

www.eurojournals.com/ejefas_12_01.pdf on 17th January 2012.

Alexandra, B. (2006), Effect of ownership structure on accounting information quality. Department of accounting and finance. University of Qalu, Finland, 13:20-41.

Ball, R. \& Brown, P. (1968).An empirical examination of accounting income numbers.Journal of Accounting Research, 6(2), 159-178. http://dx.doi.org/10.2307/2490232

Chiraz, B., Samir, T. \&Mierella, G. (2007).Disclosure quality and quality of accounting information, ownership structure. The result also show that French listed firms provides quality accounting information disclosure, Chiraz Ben Ali school of research and finance, University of Paris 12-17.

Choi F. and Mueller G. (1992), International Accounting, Prentice-Hall, 2nd Edition.

Crozier M. \& Friedberg E. (1977), L’acteuret le système, Editions du Seuil.

Dechow, P.M. (1994). Accounting earnings and cash flow as measures of firm performance: The role of accounting accruals.Journal of Accounting and Economics, 18, 3-42. http://dx.doi.org/10.1016/0165$\underline{4101(94) 90016-7}$ 
Frank, H. Kenneth, W. \& John, J. (2008). The quality of accounting ands market quality, publicly available to all investors help reduce information asymmetry, Smith School of Business, University of Maryland, 4-14.

Garcia Lara, J.M., and Mora, A., 2004. Balance sheet versus earnings conservatism in Europe.European Accounting Review, 13 (2), 261-292.

Ismail, Noor Azizi; King, Malcolm (2007).Factors influencing the alignment of accounting information systems in small and medium sized Malaysian manufacturing firms.Journal of Information Systems and Small Business, vol. 1, no. 1-2, p. 1-20. Available at:

<https://ojs.deakin.edu.au/index.php/jissb/article/view/1>. Date accessed: 30 june 2017.

Michailesco, Celine (1999). The determinants of the quality of accounting information disclosed by French listed companies. EAA Congress, 1999, Bordeaux, France. pp. 1-20.<halshs-00540570>

Nicolaou, A., (2000). A Contingency Model of Perceived Effectiveness in Accounting Information Systems: Organizational Coordination and Control Effects. International Journal of Accounting Information Systems, 1, 91-105. http://dx.doi.org/10.1016/S1467-0895(00)00006-3

Protcea, O. (2008). The effect of quality of accounting information disclosure in an organizational structure.Some empirical evidence from Roman-American University, Management Marketing Faculty 14-42. 